\title{
KENYÉRFOGYASZTÁSI SZOKÁSOK A GLUTÉNMENTES DIÉTÁBAN
}

\author{
Csapóné Riskó Tünde
}

\begin{abstract}
Absztrakt: A cöliákia egy autoimmun rendellenesség, melynek kiváltó ágense egy a gabonafélékben (búza, rozs, árpa, zab) található fehérje, a glutén. Ha egy cöliákiás személy gluténtartalmú élelmiszert fogyaszt, szervezete a glutént veszélyes anyagként érzékeli és negatívan reagál rá. A gluténra adott immunreakció során károsodik a vékonybél és akadályozódik a tápanyagok felszívódása. A cöliákia napjaink tudományos eredményei szerint nem gyógyítható, az egyetlen kezelési lehetőség az élethosszig tartó gluténmentes diéta. A cöliákia a világ népességének átlagosan 1 százalékát érinti, diagnosztizálásra azonban minden 10. eset kerül. A kenyér alapvető és igen gyakran fogyasztott élelmiszer, ami alapvetően gluténtartalmú gabonákból készül. Számos közmondásunk, szólásmondásunk is utal a kenyér központi helyére, szerepére a magyar étkezési kultúrában. A gluténmentes termékek piaca folyamatosan bövül, így hazánkban is egyre többféle gluténmentes termék közül tudnak választani a gluténmentes diétát folytatók. Primer kutatásunk során gluténmentes diétát folyatók kenyérvásárlási, -fogyasztási szokásait mértük fel.
\end{abstract}

Abstract: Celiac disease is a genetic autoimmune disorder characterized by sensitivity to gluten. Gluten is a protein found in many grain products (wheat, rye, barley and oat). When a person with celiac disease consumes gluten, his/her immune system perceives the gluten to be a harmful substance and reacts negatively. The immune reaction to gluten causes damage in the small intestine and inhibits the body's ability to absorb food nutrients. The only treatment for people with celiac disease is lifelong adherence to a gluten-free diet. Celiac disease affects about 1 in 100 individuals worldwide, but only every 10th has been diagnosed. Bread is a basic and frequently consumed food made from basically gluten-containing grains. Bread is essential part of the Hungarian dining habits. The market of gluten free foods has been continuously increasing, thus there is rather good choice in gluten-free products in Hungary also. The aim of our empirical research was to investigate the gluten-free bread purchasing and consumption habits of people following a gluten-free diet.

Kulcsszavak: cöliákia, glutén, gluténmentes diéta, gluténmentes kenyér, fogyasztói szokások

Keywords: celiac disease, gluten, gluten free diet, gluten free bread, consumer behaviour

\section{Bevezetés}

A glutén két fehérje, a gliadin és a glutenin keveréke, amely búzafélékben és azzal rokon gabonafélékben (búza, rozs, árpa, zab) található meg. A két összetevő vízzel keveredve masszává áll össze. A glutén (sikér) tulajdonképpen ragasztó-fehérje, amely jól formázhatóvá, keleszthetővé teszi a hagyományosan búzalisztböl készülö kenyereket, péksüteményeket, kelt tésztákat. Kenyérféléken, kelt tésztákon, süteményeken, kekszeken túl használják azonban sürítöanyagként is különféle szószokban, ketchup-okban (Lukács, 2014).

A cöliákia olyan autoimmun betegség, amely örökletes, környezeti (glutén) és immunológiai komponensekből tevődik össze (Klicsu-Pálfi, 2007). Az autoimmun betegség azt jelenti, hogy a szervezet valamilyen alapvetően nem káros anyagra rossz immun választ ad, megpróbálja azt elpusztítani. A cöliákia esetében a szervezet a gluténre reagál antitestek termelésével. Az immunreakció tönkreteszi a vékonybél nyálkahártyáját és a bélbolyhokat és felszívódási zavar alakul ki, hiszen normál esetben itt történne a tápanyagok, vitaminok, ásványi anyagok felszívódásának nagy 
része. Tünetei között találjuk a hasmenést, hasfájás, puffadást, zsírszékletet, fogyást, felszívódási zavarok miatti vas- és vitaminhiányt. Napjainkban a betegség klasszikus megjelenése ritkább és gyakoribbá vált a tünetekben szegényebb forma, amely bármely életkorban előfordulhat (Hanula, 2016; Hidvégi, 2016; agrotrend, 2016). A betegség megjelenésének időpontja és előfordulási gyakorisága az utóbbi 30 - 40 évben drámaian megváltozott. Korábban gyermekkori betegségként tartották számon, a diagnosztizált gyermekek többsége két évnél fiatalabb volt. A jelenlegi ismeretek szerint, amely a megbízható szerológiai módszerek eredményein alapul, a cöliákia bármely életkorban jelentkezhet (Pusztai, 2016). A cöliákia az európai lakosság 1 - 3 százalékát érinti, mintegy 5 millió embert, akiknek 80 százaléka még nem diagnosztizált. A fel nem ismert betegségnek a következményei súlyos szövődmények és társult betegségek lehetnek. Napjainkban a cöliákiával újonnan diagnosztizált betegek többsége felnőtt, sőt időskorú. Az alacsony felderítettségi arány arra utal, hogy nyolc cöliákiás emberböl csak egyet diagnosztizáltak helyesen (Gluténmentesen, 2017).

Nagy megkönnyebbülés a beteg számára, amikor végül is diagnosztizálásra kerül a cöliákia, hiszen akár hosszú éveken át tartó „szenvedésnek” kerülhet pont a végére. A cöliákia a tudomány mai állása szerint gyógyszerekkel nem gyógyítható, egyetlen elfogadott kezelési gyógymódja a szigorú gluténmentes diéta. Ez azt jelenti, hogy glutént, vagy ahhoz hasonló szerkezetü fehérjéket tartalmazó búzát, rozst, árpát, zabot és ezek keresztezett változatait tartalmazó élelmiszereket, továbbá gluténnal szennyezett élelmiszereket tilos fogyasztani. Az élelmiszereket ez alapján három csoportba rendezhetjük. Vannak glutént biztosan tartalmazók (pl. hagyományos kenyerek, péksütemények), glutént potenciálisan tartalmazók (pl. félkész ételek, öntetek) és glutént biztosan nem tartalmazók (pl. friss zöldségek, gyümölcsök, tojás). Amilyen egyszerünek tünik azonban az orvos által elöírt szigorú gluténmentes diéta, menet közben kiderül, hogy nem is annyira egyszerü követni azt. A betegeknek minden egyes nap kihívás, folyamatosan körültekintőnek, óvatosnak kell lenniük minden étellel, itallal szemben. Ez az óvatosság elkezdődik már az üzletekben, ahol igen alaposan tanulmányozzák az egyes élelmiszerek összetevőit. Otthonukon kívül, mint például munkahelyen, iskolában, rendezvényeken, éttermekben, külföldi tartózkodás alkalmával úgyszintén körültekintően mérik fel a számukra biztonságos ételeket és italokat a rendelkezésre álló kínálatból. Az étkezés ebből adódóan bizonytalansághoz, szorongáshoz és gyakran csalódáshoz vezet a legtöbb cöliákiásnál. Mivel esetükben a terápia maga a gluténmentes diéta, az étkezés egyben a terápia. Az étkezés azonban nem csak az éhség csillapítására szolgál, hanem társasági esemény is gyakran, a közösség összetartozásának egyik megjelenési formája a közös étkezés. Vannak olyan krónikus betegségek, amiket titokban lehet tartani, egy cöliákiás azonban ezt nem teheti meg, mert a biztonságos étkezés érdekében be kell vonnia környezetét. Éppen ezért sokszor érzik úgy, hogy zavarják a társaságot, kínos nekik a társasági közös étkezés, a vendégségbe járás, a folyamatos kérdezősködés és magyarázkodás. A legrosszabb következmény az, hogy a negatív élmények miatt a cöliákiások bezárkóznak és csak minimális 
társasági életet élnek. Éppen ezért fontos hangsúlyozni, hogy a cöliákia egyszerre egyéni és társadalmi feladat is (Laine, 2016).

A GfK Hungária 2010-re vonatkozó kutatásából kiderült, hogy hagyományos kenyeret szinte minden háztartás vásárol(t) Magyarországon. Annak ellenére, hogy az elmúlt 20 évben a hazai pékárupiacon legnagyobb mennyiségi részesedést jelentő fehér kenyér fogyasztása fokozatosan csökkent, a kenyér még mindig a leggyakrabban fogyasztott öt élelmiszer között található. A 15 évnél idősebb lakosság háromnegyede hetente többször fogyaszt fehér kenyeret, 58 százalékuk szinte napi rendszerességgel. A hazai háztartások vásárlási adatai alapján az egy fỏre eső fogyasztás 50 kilogramm volt a vizsgált évben. A háztartások egy év alatt 67 alkalommal vettek kenyeret. Friss kenyérre, kiflire, zsömlére és egyéb friss pékárura 196 milliárd forintot költöttek a háztartások 2010-ben (GfK, 2011).

Nagy kihívás glutén nélkül sütni-fözni, egy tésztát úgy összeállítani, hogy az ne essen szét, olyan kenyeret sütni, ami hasonló élvezeti értékkel bír, mint egy hagyományos, gluténtartalmú kenyér. Ezt megerősítheti bárki, aki próbált már gluténmentes lisztektől, lisztkeverékekből bármit is alkotni. A glutén teszi a tésztát kompakttá. A gluténmentes sütés-fözés nemcsak technológiai szempontból különbözik a hagyományostól, lelkiismeretes munkát igényel az innovatív hozzávalók kutatása és az új receptek kifejlesztése (yourlife, 2010). A gluténmentes diétában a sikérmentesség biztosítása alapvetỏ fontosságú. A cél olyan állagú és formájú tészta készítése, amely a búzalisztből készülthez a legközelebb áll. Számos sikérhelyettesítö közül lehet választani, ilyenek például a xantán, guármagliszt, agaragar, útifümaghéj, lupin rost, almarost, chia mag, stb. A sikérmentesség biztosítása mellett meg kell említenünk a rendelkezésre álló alternatív gabonaféleségeket és álgabonákat is, melyekkel kiválthatóak a gluténtartalmú gabonák. Ilyen alternatív lehetőség például a köles, teff, cirok, quinoia, amaránt, hajdina, rizs, burgonya, kukorica használata. A napjainkban kapható sütőipari termékeket alacsonyabb élvezeti érték és tápérték jellemzi összevetve öket a hagyományos termékekkel. A gluténmentes gabonák kevesebb B-vitamint, folsavat, kalciumot, vasat és élelmi rostot tartalmaznak. A hasznos prebiotikumok és probiotikumok alkalmazásával a gyártók költséghatékonyan és biztonságosan tudják növelni gluténmentes termékeik technológiai és táplálkozási minöségét is. A feldogozott gluténmentes termékek alacsonyabb vitamin- és rosttartalma miatt igen fontos, hogy a gluténmentes diétát követők minél nagyobb arányban fogyasszák az olyan gluténmentes gabonaféléket, dióféléket, magvakat, amelyeknek magas a rost-, vas-, cink- és más fontos tápanyagtartalma. A hajdina és a köles rendkívül elönyösek lehetnek a gluténmentes diéta során kialakuló hiányok pótlására (Lukács, 2016).

Azoknak, akik gluténmentes diétában kenyeret szeretnének fogyasztani, két lehetőségük van: vásárolják a gluténmentes kenyeret vagy sütnek maguknak. Számos gluténmentes kenyér gyártó és márka jelen van a magyar piacon, bár az összetétele, textúrája, színe, rugalmassága ezen kenyereknek igen eltérö, különösképpen a hagyományos kenyerekkel összehasonlítva őket. Kutatási eredmények is alátámasztják, hogy a boltok polcain sajnos sok gluténmentes kenyér gyenge minőségủ és ízü, szárazak, morzsálódó az állaguk, ami nem szimpatikus a 
friss, lágy, magasabb nedvességtartalmú kenyérféléket kereső fogyasztóknak (Ylimaki et al., 1991; Arendt et al., 2002; Gallagher et al., 2003). Ha valaki sütni szeretne kenyeret gluténmentes lisztekből és liszt keverékekből is meglehetősen nagy és egyre bővülő a választék a hazai piacon. Ezen lisztkeverékek összetétele is igen különböző, ezért is gyakori az, hogy a gyártó saját lisztkeverékéhez kenyér recepteket is ajánl.

\section{Anyag és módszer}

A kenyér alapvető és igen gyakran fogyasztott élelmiszer, ami hagyományosan búzalisztből készül. Gluténmentes diétát folyatók is fogyasztanak kenyeret, természetesen gluténmentes változatban. Primer kutatásunk célja az volt, hogy megvizsgáljuk a kenyérvásárlási és -fogyasztási szokásokat gluténmentes diétát folyatatók körében. Miután elég nagy választék áll rendelkezésre mind gluténmentes kenyerekből és gluténmentes lisztekből, lisztkeverékekből, kíváncsiak voltunk arra, hogy a válaszadók milyen gyakran és mely fő étkezésekhez fogyasztanak kenyeret, vásárolják vagy inkább sütik a kenyeret maguknak. Mindkét esetben (vásárlás sütés) vizsgáltuk a motivációkat, gyakoriságokat és a preferált márkákat. Internet alapú kérdőíves megkérdezést végeztünk 2017 januárjában Magyarországon. Az online kitölthető kérdöívet négy zárt gluténmentes Facebook közösségben osztottuk meg. Ezek a közösségek igen aktívak és nyitottak a gluténmentes életmód, illetve táplálkozás terén az egymással való információ megosztásban. A minta nagysága: 196. A kérdőívben szerepeltettünk zárt, feleletválasztós, skálás és demográfiai kérdéseket.

Válaszadóink 89,7 százaléka nő és 10,3 százaléka férfi. Ez az arány jelen esetben nem azzal magyarázható, hogy a nök fogékonyabbak a kérdöíves felmérésekben való részvételre. Egy magyarországi kutatás feltárta, hogy a cöliákia sokkal több nőt (81 százalék) sújt, mint férfit (19 százalék) (Vojnits, 2012). 24,4 százalékuk a fővárosban él, 20,5 százalékuk megyei jogú városban, 25,6 százalékuk egyéb városokban és 29,5 százalékuk egyéb településtípuson. Magyarországon hét NUTS 2 régió van, válaszadóink képviselték valamennyit. Iskolai végzettségüket tekintve, a válaszadók fele felsőfokú végzettséggel, 38,5 százalékuk érettségivel és közel 6 - 6 százalékuk 8 általánossal vagy szakmunkásképzővel rendelkezik. A válaszadók fizikai aktvitását tekintve 41 százalékuk aktív szellemi, 21,8 százalékuk aktív fizikai dolgozó, míg 20,5 százalékuk tanuló. Találunk még igen kis arányban GYES/GYED-en lévőt, munkanélkülit és nyugdíjast is. Családi állapotukat tekintve 62,8 százalékuk élettárssal élö, illetve házas, 29,5 százalékuk hajadon/nőtlen és 7,7 százalékuk elvált. Anyagi helyzetüket tekintve 44,9 százalékuk átlagos jövedelmünek, 17,9 százalékuk jelentősen átlag feletti, 15,4 százalékuk átlag alatti, 11,5 százalékuk átlag feletti jövedelmünek vallja magát. A fennmaradó válaszadók között egyenlő arányban vannak a jelentősen átlag alatti és a saját jövedelemmel nem rendelkezők. 


\section{Eredmények és értékelésük}

Az első kérdéssel azt vizsgáltuk, hogy válaszadóink milyen gyakran fogyasztanak kenyeret. Az eredményeket az 1. ábra szemlélteti.

\section{1. ábra: Gluténmentes kenyér fogyasztásának gyakorisága}

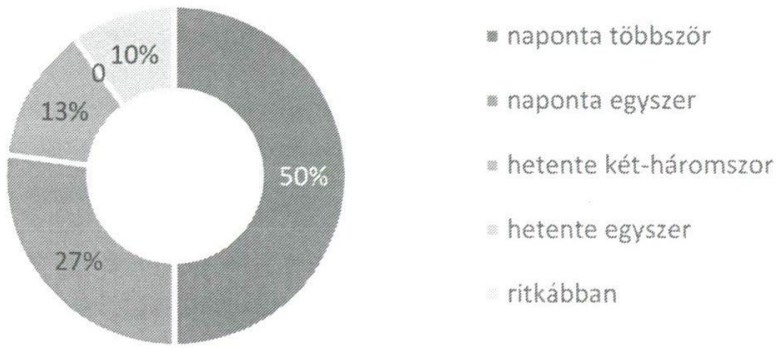

Forrás: Saját kutatás (2017) (N=196)

Van egy olyan mondás, hogy a magyarok a kenyeret is kenyérrel eszik. Amint azt az 1 . ábra is alátámasztja, a kenyér alapvető szerepet tölt be a magyar étkezési kultúrában. Naponta többször $(50 \%)$ is fogyasztják a válaszadók. Ennek magyarázata kultúránkban, tradícióinkban gyökerezik és hagyományos ételeinkre, (mint a gulyás és a számtalan pörköltféleség) vezethető vissza. A kenyér fontossága, értéke megjelenik számos szólásunkban, közmondásunkban is. (Kenyeret keres. A pap is kenyérért prédikál. Egy kenyéren élnek. Kenyere ez neki. Megette a kenyere javát. Kenyértörésre kerül. Kölcsön kenyér visszajár. Olyan, mint egy falat kenyér. Madárlátta kenyér. stb.) A reggeli a legmeghatározóbb fő étkezés Magyarországon, mint ahogy egyik szólásunk is utal rá: Reggelizz, mint egy király, ebédelj, mint egy polgár és vacsorázz, mint egy koldus. A hagyományos magyar reggeli kenyér, illetve péksütemény alapú. A reggelin túl, a legtöbb szülő gyermekének tízóraira, uzsonnára szendvicset készít, ami szintén kenyér, péksütemény alapú. Mint ahogy azt a 2. ábra szemlélteti, a reggeli kenyér nélkül csaknem elképzelhetetlen a válaszadók körében.

\section{2. ábra: Gluténmentes kenyérfogyasztás gyakorisága fö étkezésekhez}

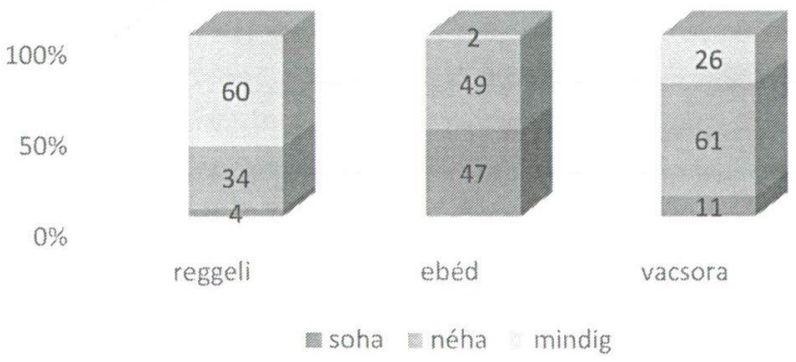

Forrás: Saját kutatás (2017) (N=196) 
A gluténmentes kenyerek különböznek hagyományos társaiktól (összetevők, szín, puhaság, rugalmasság stb.) Ezen kenyerek beszerezhetősége is más, olyan egyszerüen, könnyedén nem vásárolhatók meg, mint a hagyományos kenyerek. Ha a fogyasztó hozzáférési lehetőségei korlátozottak (pl. faluban él), feltételezhetően ritkábban vásárol kenyeret, de akkor nagyobb mennyiségben, ami elegendő neki legalább egy hétre vagy még tovább. Egy másik ésszerü magyarázat a ritkább vásárlási gyakorlatra (50\%), az, hogy a válaszadók a vásárolt kenyeret kiegészítik időnként saját maguk által sütött kenyérrel. Kutatásunk feltárta, hogy a válaszadók 51,3 százaléka többnyire vásárolja a kenyeret. A 3. ábra a gluténmentes kenyerek vásárlási gyakoriságát mutatja.

\section{3. ábra: Gluténmentes kenyerek vásárlási gyakorisága}



Forrás: Saját kutatás (\%) (2017) $(\mathrm{N}=196)$

A magyarok jellemzően inkább hagyományos üzletekben vásárolnak, mint kisboltokban, szupermarketekben és hipermarketekben. A webáruházakból való vásárlás folyamatosan emelkedő tendenciát mutat, de még közel sem olyan gyakoriságú, mint a hagyományos üzletekböl való vásárlás. A 4. ábra is alátámasztja ezt a tényt, mely a gluténmentes kenyerek vásárlási helyszíneit mérte fel. A speciális diétát követő emberek szaküzletekben nagy biztonsággal tudják megtalálni a számukra szükséges élelmiszereket és táplálék kiegészítőket, melyek többnyire nagyobb városokban lelhetök fel. A 4. ábra szemléleti, hogy a válaszadók az ilyen szaküzleteket részesítik előnyben. Öket követik a szupermarketek és a multik, mint a gluténmentes kenyérvásárlások leggyakoribb helyszínei. A szaküzletekben a gluténmentes kenyérválaszték jóval nagyobb és nagy valószínüséggel a személyes kapcsolat, az üzletek atmoszférája, a bizalom is fellelhető a háttérben. Molnárfi (2014) is említi írásában, hogy a szakboltokban érezhetően nagyobb bizalom lengi körül a vásárlókat. Interjúalanya elmondja, hogy az elöírások köztudottan nagyon szigorúak, így ha egy gyártó nem mellékelte a laboreredményt, vagyis nem bizonyított a termék ,tisztasága”, akkor több tízezer forintért külön vizsgálatra küldik. Minden vevőjüket ismerik és nagyobb távolságokról is vannak rendszeres vásárlóik. Munkatársaik zöme maga is érintett, de dietetikusokkal és élelmiszermérnökökkel is együttműködnek. Mindezek alapján joggal állíthatják, 
hogy a multik, hipermarketek nem jelenthetnek igazi konkurenciát. Megnyugtató egy cöliákiás beteg számára, hogy olyan környezetben vásárolhat, kérhet tanácsot, segítséget, ahol érintettek között van, akik valóban át tudják érezni a helyzetét. A legkézenfekvőbb oka a gluténmentes kenyér szupermarketben vagy multinál való megvásárlására az, hogy a válaszadók együtt intézik ezen termék beszerzését a többi beszerezni kívánt termékkel.

\section{4. ábra: Gluténmentes kenyér beszerzésének helyszínei}

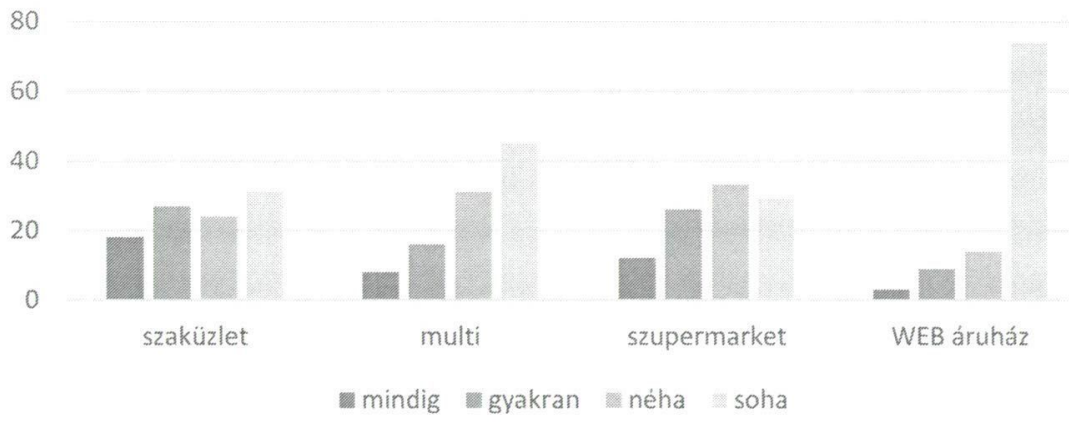

Forrás: Saját kutatás (\%) (2017) (N=196)

Megkérdeztük válaszadóinkat, hogy lojálisak-e egy adott kenyér márkához, ugyanazt a márkát vásárolják-e folyamatosan. Kutatásunk feltárta, hogy körültekintőek válaszadóink. 39,7 százalékuk azt válaszolta, hogy 'igen, többnyire', 30,8 százalékuk 'igen, mindig' és csak a fennmaradó 29,5 százalék válaszolt nemmel. A leggyakoribb, legkönnyebben fellelhető általunk felsorolt kenyérmárkák közül kellett a következőkben megjelölniük azt, hogy azokat milyen gyakorisággal (mindig, gyakran, néha, soha) vásárolják. A felsorolt márkák a következőek voltak: Schär, Mester Család, Nutri Free, Glutenix, Enjoy Free, Spar Free From, Glulu. Kutatásunk feltárta, hogy válaszadóink körében a Schär, Enjoy Free és Mester Család a legnépszerübb kenyér márkák. A kapott eredményeket az 1. táblázat szemlélteti.

\begin{tabular}{lrr}
\multicolumn{2}{c}{ 1.táblázat: Preferált gluténmentes kenyérmárkák } \\
Milyen márkájú kenyeret szokott vásárolni? & $\begin{array}{r}\text { mindig } \\
\text { gyakran }\end{array}$ \\
Schär (1) & $\mathbf{5 4 \%}$ & $\mathbf{4 5 \%}$ \\
Mester Család (3) & $\mathbf{7 \%}$ & $\mathbf{1 6 \%}$ \\
Nutri Free & $0 . \%$ & $7 \%$ \\
Glutenix & $3.5 \%$ & $\mathbf{7 \%}$ \\
Enjoy Free (Aldi) (2) & $\mathbf{2 8 . 5 /}$ & $\mathbf{1 8 \%}$ \\
Spar Free From & $3.5 \%$ & $7 \%$ \\
Glulu & $3.5 \%$ & $0 \%$ \\
Összesen & $100 \%$ & $100 \%$
\end{tabular}

Forrás: Saját kutatás (2017) 
Megkérdeztük válaszadóinkat, hogy elégedettek-e a magyarországi gluténmentes kenyérválasztékkal. Válaszadóink 48,7 százaléka nem elégedett, 37,2 százalékuk részben, 14,1 százalékuk teljes mértékben elégedett. Megkérdeztük véleményüket a Magyarországon kapható gluténmentes kenyerek minőségével kapcsolatosan is. A válaszadók 46,2 százaléka nincs megelégedve, 43,6 százalékuk részben van megelégedve, míg 10,2 százalékuk teljes mértékben meg van elégedve. A gluténmentes termékek ára magasabb, mint a hagyományos termékek ára, így vizsgáltuk azt is, hogy mennyire vannak megelégedve a Magyarországon kapható gluténmentes kenyerek árával. Összegzésképpen megállapíthatjuk, hogy válaszadóink meglehetősen magasnak tartják a gluténmentes kenyerek árát (drága: 44,9\%; irreálisan drága: $34,6 \%$; kissé drága: $19,2 \%$; reális: $1,3 \%$ ). Az eddig ismertetett eredménynek (választék, minőség, ár) magyarázatként is szolgálhatnak a következö eredményhez, miszerint válaszadóink 74,4 százaléka szokott kenyeret sütni, bár a kenyérsütés gyakorisága eltérő. Vizsgáltuk, hogy miért és milyen gyakorisággal sütnek kenyeret. A következő eredményeket kaptuk: 23,1 százalékuk nincs megelégedve a megvásárolható kenyerek minőségével, ugyancsak 23,1 százalékuk drágának találja a kenyerek árát, 11,5 százalékuk pedig csak a saját maguk által sütött kenyérben bíznak meg stb. A kenyérsütés gyakoriságára vonatkozó kérdésünkre a következő eredményeket kaptuk: 21,8 százalékuk hetente kétszer süt, 24,4 százalékuk hetente egyszer, 25,6 százalékuk ritkábban, 2,6 százalékuk egyéb választ adott. Ismét rákérdeztünk a márkahüségre is. Kíváncsiak voltunk rá, hogy válaszadóink lojálisak-e egy adott gluténmentes kenyérliszt keverékhez vásárlásaik során. A következő eredményeket kaptuk: 57,7 százalékuk többnyire márkahü, de szokott kísérletezni más márkákkal is, 21,8 százalékuk mindig ugyanazt a márkát használja, 17,9 százalékuk nem vallja magát márkahűnek, 2,6 százalékuk egyéb választ adott. Ezek alapján kijelenthetjük, hogy válaszadóink lojálisak a már megszokott márkáikhoz. A következő kérdéssel azt kívántuk kideríteni, hogy az általunk felsorolt gluténmentes kenyér lisztkeverékek (Anna Panni, Doves Farm, Mester Család, Amisa, Barbara, Bauck Hof, Dia-Welness, Emese, FE-MINI, Glutenix, 'saját lisztkeverékem', Nutri free, Szafi free) közül melyek a legnépszerübbek, melyik márkát milyen gyakorisággal vásárolják. Ezen felsorolt márkák közül a Szafi free $(19,2 \%)$ bizonyult a legnépszerübbnek, ezt követte a 10,3 - 10,3 százalékkal a 'saját lisztkeverékem' és a Nutri free, majd 9 százalékkal harmadik legnépszerübb márkaként a Mester Család jelent meg. Amint ez már kiderült az elözőekben, gyakori válaszadóink körében a kenyérsütés. Több féle lehetőség kínálkozik kenyérsütésre, mint elektromos sütő, gázsütő, kenyérsütő gép. A továbbiakban azt vizsgáltuk, hogyan/miben sütnek kenyeret. A válaszadók 47,4 százaléka elektromos sütőben, 16,7 százaléka gáz sütőben és 11,5 százaléka kenyérsütő gépben süt kenyeret. A fennmaradó válaszadók egyéb lehetőséget neveztek meg, mint például gofri sütő, kemence vagy nem sütnek kenyeret. Ahogy az már említésre került, a gluténmentes kenyerek több szempontból is különböznek a hagyományos kenyerektől. Szerettük volna kideríteni, hogy válaszadóink számára milyen is az ideális kenyér. A következő jellemzőket soroltuk fel számukra, melyek fontosságát 1-7-es Likert-skálán kellett jelölniük: puha, fehér, barna, magvas, cipó 
formájú, hosszabb ideig puha. Leggyakoribb válaszok az egyes jelzőkre a következőek lettek:

$\begin{array}{lll}\text { - } & \text { puha: } & \text { fontos: } 43.5 \% \text { + nagyon fontos: } 43 \% \\ \text { - } & \text { fehér: } & \text { egyáltalán nem fontos: } 27 \% \\ \text { - } & \text { barna: } & \text { semleges: } 26 \% \\ \text { - } & \text { magvas: } & \text { semleges: } 22 \% \\ \text { - } & \text { cipó formájú: } & \text { egyáltalán nem fontos: } 24 \% \\ \text { - } & \text { hosszabb ideig puha: } & \text { fontos: } 45 \% \text { + nagyon fontos: } 35 \%\end{array}$

Felmérésünkből kiderült, hogy leginkább a puhasággal és minél hosszabb ideig tartó puhasággal jellemezhető válaszadóink szerint az ideális kenyér. Egyáltalán nem szükséges, hogy fehér legyen vagy cipó formájú, a barna szín és magokkal való dúsítás pedig semleges megítélést kapott.

\section{Következtetések, összegzés, záró megjegyzések, záró gondolatok}

A cöliákia egy krónikus autoimmun rendellenesség. Világszinten 100 emberből 1, Magyarországon a népesség 1 - 2 százaléka érintett. Az egyedüli lehetőség a betegséggel való együttélésre az élethosszig tartó szigorú gluténmentes diéta. Ez a búza, rozs, árpa, zab szigorú kiiktatását jelenti az étrendből. Hazánkban és a világ nagy részén a kenyér alapvetően gluténtartalmú gabonákból készül. A kenyér központi helyet foglalt és foglal el a magyar étkezési kultúrában, napjainkban is az 5 leggyakrabban vásárolt termékek kötött szerepel. A gluténmentes piac világszinten folyamatosan bővül, ez jó hír a gluténmentes diétát folytatók számára. Így gluténmentes kenyerekböl és liszt keverékekböl is egyre nagyobb a kínálat. Ezek a kenyerek azonban összetételükben, megjelenésükben, állagukban, élvezeti értékükben különböznek hagyományos társaiktól. Primer kutatásunkkal gluténmentes diétát folytatók gluténmentes kenyérvásárlási és -fogyasztási szokásait mértük fel. Primer kutatásunkkal feltártuk:

- a kenyér központi helyet foglal el a gluténmentes diétát folytatók étrendjében is,

- a reggeli gyakorlatilag elképzelhetetlen kenyér nélkül még a gluténmentes diétában is,

- a válaszadók 51,3 százaléka többnyire vásárolja a kenyeret,

- a válaszadók 50 százaléka ritkábban, mint hetente, míg 24 százaléka heti rendszerességgel vásárol gluténmentes kenyeret,

- válaszadóink a szakboltokat részesítik előnyben kenyérvásárlásaik során,

- a válaszadók 2/3-a lojális az általa vásárol gluténmentes kenyér márkához, a legnépszerübb márkáknak pedig a Schär, Enjoy Free és a Mester Család bizonyultak,

- a gluténmentes kenyérválasztékot elfogadhatónak, de az árakat magasnak találják a válaszadók,

- a válaszadók 74,4 százaléka süt kenyeret, de a kenyérsütés gyakorisága eltérö, 
- a válaszadók több, mint 3/4-e lojális az általa megszokott kenyérliszt keverékhez, a legnépszerübb márkáknak pedig a Szafi free, "saját lisztkeverékem", Nutri free és a Mester Család bizonyultak.

Még mindig kihívás a gluténmentes pékségek számára a gluténmentes kenyerek minőségének, állagának, élvezeti értékének javítása. A gluténmentes termékek magasabb ára megterhelő a gluténmentes diétát folytatók számára. Ez annál inkább is súlyos kérdés, mert az egészségügyi okokból diétázni kényszerülök számára nem lehetséges „más” élelmiszerek választása. A márkahüség erősnek bizonyult, ami lehetőséget kínál az erős márkák számára újabb termékekkel megjelenni a gluténmentes piacon.

\section{Irodalomjegyzék}

agrotrend (2016): Gluténmentes élelmiszerek: változás a szabályozásban. $<$ http://www.agrotrend.hu/piac/elelmiszergazdasag/glutenmentes-elelmiszerek-valtozas-aszabalyozasaban> (2017.10.17)

Arendt, E. K., O'Brien, C. M., Schober, T. J., Gallagher, E., Gormley, T. R. (2002): Development of gluten-free cereal products. Farm Food, 12 (part 2): 21-27.

Gallagher, E., Gormley, T. R., Arendt, E. K. (2003): Crust and crumb characteristics of gluten free breads. Journal of Food Engineering, 56 (2): 153-161.

GfK (2011): Friss pékáruknál a kisboltok mennyiségi részesedése 47 százalék. <http://www.piackutatasok.hu/2011/11/gfk-friss-pekaruknal-kisboltok.html> (2017.10.17)

Gluténmentesen (2017): Fókuszban a coeliakia. Gluténmentesen. A Lisztérzékenyek Érdekképviseletének Országos Egyesülete hivatalos lapja, 21 (1): 20.

Hanula Zs. (2016): Mentes = egészséges? <http://index.hu/tudomany/2016/06/13 /mentes_egeszseges/> (2017.10.17)

Hidvégi E. (2016): Gabonamentes étrend: Divat vagy terápia? Paramedica, 15 (5): 21.

Klicsu N., Pálfi E. (2007): A gluténmentes diéta költségei. Új diéta. A magyar dietetikusok lapja, 2 (6): 4-6 <http://www.ujdieta.hu/index5556.html?content =699> (2017.10.17)

Laine, E. (2016): A coeliakia hatása a mindennapi életünkre. Gluténmentesen. A Lisztérzékenyek Érdekképviseletének Országos Egyesülete hivatalos lapja, 20 (3): 6-7.

Lukács A (2014): Nyakunkon a gluténterror: kényszer és üzlet. <http://hvg.hu/plazs/20140701_Glutenhorror> (2017.10.17.)

Lukács K. (2016): Használható az áthúzott gabonakalász. Gluténmentesen. A Lisztérzékenyek Érdekképviseletének Országos Egyesülete hivatalos lapja, 20 (3): 12-15.

Molnárfi K. (2014): Bombaüzlet lett az ételallergia - Miért drága, he semmi nincs benne? <https://vs.hu/gazdasag/osszes/bombauzlet-lett-az-etelallergia-miert-draga-ha-semmi-nincsbenne-1110\#!s0> (2017.10.17.)

Pusztai J. (2016): Csipkerózsika projekt. Gluténmentesen. A Lisztérzékenyek Érdekképviseletének Országos Egyesülete hivatalos lapja, 20 (4): 10-11.

Vojnits B. (2012): Bármely életkorban lecsaphat a lisztérzékenység. <http://semmelweisfigyelo.hu/hu/osszes_kiemelt_cikk/hir/3060> (2017. 10.17)

Ylimaki G. - Hawrysh Z. J. - Hardin R. T. - Thomson A. B. R. (1991): RSM in the development of rice flour yeast breads: Sensory evaluation. Journal of Food Science, 56 (3): 751-759.

yourlife (2010): Édes mestermüveket alkotni müvészet. yourlife Schär magazin a jobb életminöségért, $16(40)$ : 3-5. 